Acta vet. scand. $1977, \mathbf{1 8}, 509-514$.

From the National Veterinary Institute, Oslo, Norway.

\title{
COMPARATIVE GROUPING OF MASTITIS STREPTOCOCCI BY MEANS OF CO-AGGLUTINATION AND PRECIPITATION
}

\author{
By
}

Finn Saxegaard

\begin{abstract}
SAXEGAARD, F.: Comparative grouping of mastitis streptococci by means of co-agglutination and precipitation. Acta vet. scand. 1977, 18, 509-514. - Two hundred bovine mastitis streptococcal strains belonging to groups $\mathrm{B}, \mathrm{C}, \mathrm{E}, \mathrm{G}$ and $\mathrm{L}$ were tested comparatively by means of the co-agglutination and precipitation technique. Identical results were obtained with the two tests in 191, or $95.5 \%$, of the strains. Six strains, which could not be grouped by co-agglutination, proved to belong to group $B$ when grouped by precipitation. On the other hand, one strain which proved to belong to group $G$ and two strains to group L when grouped by co-agglutination, could not be grouped by precipitation. Some cross-reactivity was observed between groups $A$ and $C, B$ and G, B and L. Only a few $L$ strains showed marked cross-reactivity which was not easily distinguished from specific reactions. However, the cross-reactivity ought to be eliminated by dilution or adsorption. Using the precipitation test as a supplementary method, the easy and rapid co-agglutination test was found to be a suitable procedure for routine grouping of mastitis streptococci.
\end{abstract}

co-agglutination; precipitation; streptococci; mastitis.

Since its introduction by Lancefield in 1933, the precipitation technique, with its various modifications, has been the standard test for the routine grouping of streptococci in diagnostic laboratories. During recent years, several attempts have been made to group streptococci by means of the co-agglutination technique which was introduced for the grouping of streptococci by Christensen et al. in 1973. These authors examined 179 strains and Tebbutt et al. (1976) 245 strains of groups A, B, C, D and G. Edwards \& Larsen (1974) examined several strains, Holth Haug (1974) 246 strains, Arvilommi (1976) 126 strains, Hahn \& Nyberg (1976) 150 strains and Hryniewicz et al. (1976) 
92 strains, all of which belonged to group A, B, C and G. All these strains were, with one exception, either laboratory reference strains of not-indicated origin, or strains isolated from human clinical material. The strains of Hahn \& Nyberg originated from human beings and several animal species. However, there are no reports of the co-agglutination test applied to streptococci causing mastitis in domestic animals. This paper describes a systematic comparative grouping, by the co-agglutination and precipitation techniques, of 200 streptococcal strains isolated from cases of mastitis in cattle.

\section{MATERIALS AND METHODS}

Streptococcal strains. The streptococcal strains used in this study were isolated from milk samples sent to the Mastitis Laboratory at the Institute for routine examination.

Antisera. Anti-streptococcal sera used for both co-agglutination and precipitation were obtained from The Wellcome Research Laboratories; Beckenham, Kent, England.

Trypsinization of streptococci. Overnight cultures of streptococci in Todd-Hewitt broth were trypsinized as described by Christensen et al. (1973) with the exception that a $5 \%$, instead of $0.5 \%$, solution of trypsin was used.

Preparation of group-specific staphylococcal reagents. A $10 \%$ suspension, in phosphate-buffered saline, of formaldehyde and heat-treated protein A-containing Staphylococcus aureus strain Cowan I (NCTC 8530) was prepared according to the method of Kronvall (1973) at The National Institute of Public Health, Oslo.

The coating procedure was performed as described by Christensen et al.

Grouping by precipitation was done as described by Lancefield (1933).

Grouping by co-agglutination. One drop of trypsinized streptococcal culture was mixed with one drop of group-specific staphylococcal reagent on a glass slide. The slide was tilted and observed for co-agglutination for $1 \mathrm{~min}$. For practical purposes a longer observation time was not found valid.

Co-agglutination and precipitation tests were performed independently of each other. 


\section{RESULTS}

The results of grouping of 200 streptococcal strains are shown in Table 1. The results may be summarized as follows:

Identical results were obtained with the precipitation technique and the co-agglutination technique in $191(95.5 \%)$ of the 200 strains examined. Of these 200 strains $197(98.5 \%)$ could be grouped by precipitation and 194 (97\%) by co-agglutination. Of the six B strains, which could only be grouped by precipitation, two showed auto-agglutination, while four showed a weak, or negative, co-agglutination reaction. On the other hand, one $G$ strain and two $L$ strains could only be grouped by co-agglutination.

T a b l e 1. Comparative grouping of 200 mastitis streptococcal strains by means of co-agglutination and precipitation.

\begin{tabular}{|c|c|c|c|c|c|c|c|c|}
\hline & & \multicolumn{7}{|c|}{ Precipitation } \\
\hline & & B & C & $\mathbf{E}$ & $\mathbf{G}$ & $\mathbf{L}$ & $\mathrm{Ng}^{\star}$ & Total \\
\hline \multirow{7}{*}{ 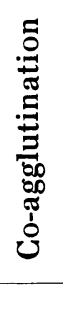 } & B & 55 & & & & & & 55 \\
\hline & C & & 118 & & & & & 118 \\
\hline & $\mathrm{E}$ & & & 2 & & & & 2 \\
\hline & G & & & & 5 & & 1 & 6 \\
\hline & $\mathbf{L}$ & & & & & 11 & 2 & 13 \\
\hline & $\mathrm{Ng}$ & 6 & & & & & & 6 \\
\hline & Total & 61 & 118 & 2 & 5 & 11 & 3 & 200 \\
\hline
\end{tabular}

* non-groupable.

As to cross-reactions, the $\mathrm{C}$ strains reacted invariably with anti-group $A$ staphylococcal reagent. Furthermore, there was some cross-reactivity between certain $B$ and $G$ strains. However, all these cross-reactions were weak and could easily be distinguished from specific homologous reactions. The only cross-reaction of importance was that shown by certain $L$ strains with anti-group B staphylococcal reagent. This cross-reactivity was so strong that these particular $L$ strains were identified on the basis of the experience that none of the $55 \mathrm{~B}$ strains showed any cross-reactivity with anti-group $L$ staphylococcal reagent. 


\section{DISCUSSION}

In agreement with Christensen et al. (1973), but in contrast to Hahn \& Nyberg (1976), trypsinization of the streptococci was found necessary for co-agglutination.

The cross-reactions between groups $A$ and $C$ and between groups B and G may, as indicated by Hryniewicz et al. (1976), be due to the possibility that strains belonging to different groups may possess common surface antigens e. g. T proteins. Whether this applies to the cross-reactivity between groups $B$ and $L$ in the present study is not known. However, non-specific reactions of this nature may be eliminated by the dilution of sera as suggested by Hryniewicz et al., or by adsorption as performed by Tebbutt et al. (1976). One of the distinctly cross-reacting $\mathrm{L}$ strains was prepared for precipitation and grouped against B and $\mathrm{L}$ antiserum. Although there was a stronger reaction with the homologous L serum, the strain also reacted distinctly with B serum. Thus, in the case of the particular $L$ strains the precipitation test was no more specific than the co-agglutination test. Such strains could easily be misinterpreted by both techniques unless other current criteria such as the CAMP reaction and aesculin hydrolysis are also evaluated. The failure of some B strains to react in the co-agglutination test may, as indicated by Hryniewicz et al., be due to the possibility that the type polysaccharide antigen could inhibit the antibody from reacting with the group polysaccharide antigen. Whatever the reason, this is, at the present time, the major shortcoming of the co-agglutination technique.

As to the use of commercial sera for the co-agglutination test, the results of the present study diverge somewhat from those previously reported in the literature. Christensen et al. found commercial Difco or Wellcome sera inferior because they cross-reacted to a considerable extent. Hryniewicz et al. found two sets of commercial sera of not-indicated origin inferior for the reason that they gave weak, or negative, reactions which were attributed to a low antibody content. On the other hand, Tebbutt et al. found Difco and Wellcome sera satisfactory although some of them had to be adsorbed. In the present study, Wellcome sera were used and found to be of reasonably good quality.

Apart from the B strains mentioned, which could not be grouped probably because of some blocking effect, the antibody 
content of the sera seemed to be adequate. In fact, one G strain and two $\mathrm{L}$ strains, which could not be grouped by precipitation, could be grouped by co-agglutination. Routine diagnostic laboratories will generally not have access to highly potent antisera which are produced in limited quantities for special research purposes. Accordingly, such laboratories must resort to commercial sera.

The co-agglutination test is simple, rapid and easy to perform. The present study shows that the degree of cross-reactivity is not higher than that it may be overcome by dilution or adsorption of sera. The failure to group certain B strains necessitates the use of the precipitation test as a supplementary test. With these shortcomings in mind the co-agglutination test may be applied as a routine test for the grouping of streptococci associated with mastitis in domestic animals.

\section{REFERENCES}

Arvillommi, H.: Grouping of beta-haemolytic streptococci by using coagglutination, precipitation or bacitracin sensitivity. Acta path. microbiol. scand. Sect. B. 1976, 84, 79-84.

Christensen, P., G. Kahlmeter, S. Jonsson \& G. Kronvall: New method for the serological grouping of streptococci with specific antibodies adsorbed to protein A-containing staphylococci. Infect. Immun. 1973, 7, 881-885.

Edwards, E. A. \& G. L. Larson: New method of grouping beta-hemolytic streptococci directly on sheep blood agar plates by coagglutination of specifically sensitized protein A-containing staphylococci. Appl. Microbiol. 1974, 28, 972—976.

Hahn, G. \& I. Nyberg: Identification of streptococcal groups A, B, C and $\mathrm{G}$ by slide co-agglutination of antibody-sensitized protein A-containing staphylococci. J. clin. Microbiol. 1976, 7, 99-101.

Holth Haug, R.: Gruppering av streptokokker. (Grouping of streptococci). Norsk Vet.-T. $1974,86,170-174$.

Hryniewicz, W., P. B. Heczko, R. Lütticken \& L. W. Wannamaker: Comparison of three methods for grouping streptococci. J. clin. Microbiol. 1976, 4, 28-31.

Kronvall, G.: A rapid slide-agglutination method for typing pneumococci by means of specific antibody adsorbed to protein Acontaining staphylococci. J. med. Microbiol. 1973, 6, 187-190.

Lancefield, R.: Serological differentiation of human and other groups of hemolytic streptococci. J. exp. Med. 1933, 57, 571-595.

Tebbutt, G. M., D. J. Coleman \& D. McGhie: Grouping of beta-haemolytic streptococci with group-specific antibodies adsorbed to staphylococcal protein A. J. clin. Path. 1976, 29, 1085-1087. 


\section{SAMMENDRAG}

Komparativ gruppering av mastittstreptokokker ved hjelp av koagglutinasjons-og presipitasjonsmetoden.

To hundre streptokokkstammer isolert fra tilfelle av mastitt hos storfe ble gruppet ved hjelp av koagglutinasjons- og presipitasjonsmetoden og viste seg å tilhøre Lancefields gruppe B, C, E, G og L. Identiske resultater med de 2 metoder ble oppnådd med 191 eller 95,5 \% av stammene. Seks stammer som ved presipitasjon viste seg å tilhøre gruppe $B$, lot seg ikke gruppe ved koagglutinasjon. En stamme som ved koagglutinasjon viste seg å tilhøre gruppe $\mathrm{G}$ og 2 som viste seg å tilhøre gruppe $L$, lot seg ikke gruppe ved presipitasjon. En viss kryssreaktivitet ble observert henholdsvis mellom gruppe A og C, gruppe B og G, gruppe B og L. Bortsett fra noen få L stammer var kryssreaktiviteten som bør kunne elimineres ved fortynning eller adsorpsjon av sera, ikke mer uttalt enn at den lett kunne adskilles fra spesifikke reaksjoner. Med bruk av presipitasjonstesten som supplerende test ble den enkle og hurtige koagglutinasjonstesten funnet å være vel egnet som rutinetest ved grupping av mastittstreptokokker.

(Received July 13, 1977).

Reprints may be requested from: Finn Saxegaard, The National Veterinary Institute, Postbox 8156, Oslo Dep., Oslo 1, Norway. 